\title{
The Effect of Total Quality Management, Enterprise Resource Planning and the Entrepreneurial Orientation on the Organizational Performance: The Mediating Role of the Organizational Excellence --- A Proposed Research Framework
}

\author{
Hassan Saleh Al-Dhaafri \& Rushami Zien Bin Yusoff \\ School of Business Management, College of Business, Universiti Utara Malaysia, Malaysia \\ Abdullah Kaid Al-Swidi (Corresponding author) \\ School of Quantitative Sciences, College of Arts and Sciences, University Utara Malaysia, Malaysia \\ Tel: 60-1-2466-2754 E-mail: swidi@uum.edu.my
}

Received: November 30, 2012

Accepted: December 10, 2012

Online Published: January 5, 2013

doi:10.5430/ijba.v4n1p66

URL: http://dx.doi.org/10.5430/ijba.v4n1p66

\begin{abstract}
Organizational performance and organizational excellence are the main two focuses of the management of any organization. In fact, the resources of an organization, either tangible or intangible, can distinguish the level of performance of one organization from its rivals. The question always is what are the key success factors that can enhance the organizational strategy implementation initiatives to produce value and create the competitive advantage. In today's changing business environment, improvement and development of internal resources are very crucial to compete externally and globally. This paper aims to review the literature related to the organizational performance and explains the potential effects of TQM, ERP and EO. Given that not all the strategy implementation initiatives are fruitful, this paper attempted to establish an explanation of the mechanism through which such strategies can enhance the overall organizational performance. Based on a thorough review of the extant literature and the theoretical foundation, a research model was proposed. The proposed model is grounded by the fact that only excellent, innovative and differentiated companies and products can excite the customers and succeed in a turbulent business environment.
\end{abstract}

Keywords: Entrepreneurial orientation, Organizational excellence, Organizational performance, TQM, ERP

\section{Introduction}

In today's competitive business environment, organizations need to evaluate their internal and external environment for opportunities and challenges in order to sustain their growth and remain competitive (Ramlall, 2002). In such a competitive environment, they should grow, survive, and seek excellence by leading the innovation.

Organizational performance has been the concern of both academics and practitioners during the last many decades as the ultimate outcome of utilization of tangible and intangible resources. Intangible resources are considered more important than tangible resources for the effectiveness and the success of organizations (Al-Swidi \& Mahmood, 2011). In the management literature, organizational performance construct has been extensively investigated. The great attention given to the organizational performance construct was driven by the desire to identify the determinants of high organizational performance. In other words, a plethora of research is extant in the literature examining the effect of some strategies on the performance.

Many strategies have been confirmed to have a significant effect on the overall organizational performance. More specifically, some innovative practices and strategies such as TQM, ERP systems, entrepreneurial orientation that develops the entrepreneurial culture have been reported to influence significantly the organizational performance. Unfortunately, the results regarding the effect of these practices and strategies have been inconclusive in the management literature. For example, Total Quality Management, as a management philosophy that concerns the overall organizational quality through continuous improvement to achieve a high level of customer satisfaction, QM, 
has been widely confirmed as a critical determinant of an enhanced organizational performance and competitive advantage (Douglas \& Judge, 2001). While the effect of TQM on the organizational performance has been confirmed by many studies (Arawati, 2005; Li et al., 2003; Yasin et al., 2004), some other studies argued that not all TQM initiatives were successful (Samson \& Terziovski, 1999; Sanchez- Rodriguez \& Martinez-Lorente, 2004; Sohal \& Terziovski,2000). To resolve this inconsistency and bridge this theoretical gap, there have been many calls for more research to be extended.

Due to the huge volume of the data acquired by any business organization, it has become necessary to have an integrated system that helps in organizing the data and facilitate their use in decision making processes. As a result, ERP systems have been gaining a growing popularity and importance as a significant resource of organizational performance. In developed countries, ERP systems have been widely used and employed in public and private organizations. However, the employment of ERP systems in developing countries is still in its infancy phase for various reasons (Huang \& Palvia, 2001). ERP systems, have been argued by Jha and Joshi (2007) to be one of the most significant technological innovations in the last two decades. In practice, the findings regarding the performance implications of ERP are conflicting. While some researchers such as (Davenport \& Brooks, 2004; Irani \& Love, 2001) confirmed the value added to organizations by employing the ERP systems, other researchers such as (Wieder et al., 2006; Hunton et al., 2003; Velcu, 2007) claimed that ERP systems may have negative results on performance. These results, however, require further investigation on what are the issues regarding the ERP implementation and what are the potential key success factors.

Due to the planning-oriented focus of the leading companies and their focus in developing creative business environment, entrepreneurial orientation construct has been gaining an increasing attention from researchers and scholars all over the world as a determinant of organizational performance and competitive advantage (Barrett \& Weinstein, 1998; Covin \& Miles, 1999; Covin \& Slevin, 1991; Lumpkin \& Dess, 1996; Zahra et al., 1999; Zahra \& Covin, 1995). The importance of EO strategy is justified by its focus to foster innovation, proactiveness, and tolerating risk in order to excite new customers and retain the existing ones (Zahra, 1991; Zahra et al., 1999). The empirical literature reveals that the findings regarding the effect of EO on organizational performance have been conflicting (Li et al., 2009; Wiklund \& Shepherd, 2005). From another perspective, some other studies doubted the appropriateness of the entrepreneurial orientation strategy for organizational effectiveness (Li et al., 2009; Wiklund \& Shepherd, 2005). These findings necessitate the examination of some other intervening variables that might act as the mechanism that explain how EO can enhance the overall organizational performance. As a result of the significant role of organizational culture on organizational performance and the competitive advantage (Scholz, 1987), the effect of EO on performance could be through its role in the development of the entrepreneurial culture which is necessary for the organizational effectiveness.

The fast paced technological advancements have changed the quality and quantity of the customers' demand. With these challenges, organizations to keep in business have to make significant changes in their doing business. That is they have to be able to foresee the future market opportunities, get involved in risky initiatives, encourage new business ideas and keep effective connections with customers. In other words, organizations should develop their entrepreneurial culture in order for them to grow or even survie (Dess et al., 1999). Without such entrepreneurial culture, organizations will be left behind due to their unablity to satisfy the critical customers' demand.

In the light of the resource based vew of the firm theory, the organizational competitive advantage is influenced by the internal resources (Barney, 1986). Organizational innovative capabilities such as total quality management (TQM), enterprise resource planning (ERP), entrepreneurial orientation (EO), and entrepreneurial organizational culture (EOC) are considered organizational capabilities that create the competitive advantage.

The main question, however, is how these innovative practices are expected to enhance the organizational performance and create the competitive advantage? In other words, what is the mechanism that explains the impact of innovative strategy's implementation on the organizational performance? The answer to these questions is the main driver of this paper. As discussed further later, the implementation of any innovative strategy is meant to enhance the organizational excellence that, in turn, enhances the overall performance due to the established connection with the technology driven and critical customers' demands.

Organizational excellence, according to Antony and Bahattacharyya (2010), can be seen and calculated based on the relationships between various variables of performance. Business excellence sustains the organization capability to deal with change (Oakland Consultation, 2005). For achieving Business excellence, managers have to have a clear vision that will drive the organization to achieve its goals and objectives (Oakland Consultation, 2005), delivering 
value and managing organizations for stakeholders. Excellence is regarded as the highest level of performance (Antony \& Bahattacharyya, 2010); therefore organizations should care more in their performance.

Currently, many organizations are seeking the organizational excellence, but unluckily many of them could not achieve this goal due to the lack of understanding of what is the organizational excellence (Dahlgaard, 2003). The term organizational excellence has lately appeared to be the same as the term business excellence with the difference that organizational excellence may be used more to public sector organizations and business excellence to private sector (McAdam, 2000).

The emphasis of this study on the importance of TQM, ERP, EO to the organizational performance and competitive advantage is in line with the premises of the RBV theory and the knowledge based theory. The organizational capabilities can be the basis of the competitive advantage and the unique strategic position of an organization (Barney, 1986, 1991). All the strategy implementation initiatives of an organization would not be happening unless they differentiate that particular organization from other business entities. This differentiation should be reflected in all the organizational activities. Meaning that, the level of organizational excellence should be the natural outcome of all the innovative strategy implementation initiatives that enhance the overall organizational excellence.

This study has tried to establish the foundation by introducing the organizational excellence as the mechanism through which TQM, ERP and EO can enhance the overall organizational performance. Detailed discussions are provided in the subsequent sections and the interrelationships hypothesized were developed calling for empirical future studies for further investigation.

\section{Theoretical Foundation}

In the development of the structural relationships among the variables of the study, the Resource-Based View of the firm theory and the Knowledge based theory were integrated. The following sections briefly describe these theories to provide deeper understanding on how they might explain the hypothesized relationships.

\subsection{Resource-Based View Theory}

In the strategic management literature, the resource-based view of the firm (RBV) has been considered as one of the most and fast growing research area in the last few decades (Galbreath, 2005). This theory was first introduced by Wernerfelt (1984). He argued that the organizational success is determined by internal resources. These resources can be either tangible or intangible assets (Collis, 1994), or capabilities such as knowledge and accumulated skills (Teece et al., 1997).

The RBV conceptualizes the firm as a package of resources, where several resources differ in importance for generating an added value for a firm (Barney, 1991). Barney (1991) argued that the firm's resources are employees' knowledge and skills, the firm's reputation, the capital equipment, and brand names. In addition, he added that the resources of the firm are the most significant factors in determining the sustainable competitive advantage. Moreover, the main sources of competitive advantage to achieve superior performance are valuable, rare, and incomparable resources of an organization. They considered as the intangible strategic resources (Barney, 1991, 2002).

In addition to that, the RBV emphasizes on the match between the available opportunities and the organizational capabilities. Therefore, the RBV's mechanism is to take into consideration the full usage of available resources to construct the core competencies for achieving and sustaining competitive advantage (Makadok, 2001). It is difficult for competitors to achieve the same level of competitive advantage if organization considers several factors such as human capabilities, access to useful information resources, and the internal organizational strategies (Barney, 1986; Russo \& Fouts, 1997). Therefore, organizations should establish the link between external environment and internal capabilities to accomplish the required competitive strategic situation.

In relation to the implication of RBV on the competitive advantage of the organization, the RBV focuses on the importance of resources in originating and sustaining competitive advantage of the organization, therefore, it should improve the mechanism of choosing the resources with great potential value (Makadok, 2001). In addition, organizations should be aware of the internal and external environment to be able to plan and design the most suitable and effective action plans (Barney, 1986). Moreover, the organizational capabilities enhance and increase the significance of the available resources and assist in matching the effective use of these resources (Prahalad \& Hamel, 1990).

Particularly, the purpose of this study is to examine the impact and the relation between TQM, ERP, and EO in the organizational performance. The comprehensive literature review shows that the variables used in this study have been underpinned theoretically by the RBV. For example, TQM has been regarded as one of the main resources of 
competitive advantage (Reed et al., 2000; Tena, 2004). EO is also considered another source of competitive advantage (Weerawardena \& Coote, 2001). In addition, ERP systems can help the organization to create generic processes where customized processes might be the source of competitive advantage (Davenport, 1998).

Thus, the previous arguments disclosed that the TQM, ERP, EO and the entrepreneurial culture can be considered to be among the main sources of the organizational competitive advantage.

\subsection{Knowledge-based View Theory}

The resource-based theory of the firm has received attention in the last two decades of the twentieth century as an alternative to the competitive advantage or product-based (Porter, 1980). However, Conner and Prahalad (1996) argued that based on the resources and capabilities theory of the firm, knowledge is regarded as the source of competitive advantage. Therefore, knowledge management is very crucial for the innovation process (Powell et al., 1998) and for successful New Product Development (NDP) strategies (Li \& Calantone, 1998).

Knowledge-based view (KBV) has been argued by some researchers (Grant, 1996; Decarolis \& Deeds, 1999) to be an outgrowth of resource-based view theory where the concept of resources is prolonged to have intangible assets, in particular, Knowledge-based resources. Earlier, Polanyi (1962) pointed out that in contrast with the tradition concept of knowledge, a newer view of knowledge has emerged based on the distinction between tacit and explicit knowledge. Therefore, according to the tacit knowledge characteristics, knowledge is regarded the most probably to become a source of competitive advantage in the innovation process (Prahalad \& Hamel, 1990). In addition, innovation transforms the tacit knowledge into explicit knowledge (Zack, 1999).

In relation to that, Subramaniam and Youndi (2005) pointed out that the innovative capability of the firm depends closely on the intellectual assets and knowledge that it has. In connection with that, Nonaka and Takeuchi (1995) added the ability of the firm to deploy those assets and knowledge, and seeing the innovation process as the most knowledge intensive business processes. Therefore, KBV can be a beneficial framework to develop a firm innovation in an effective way (Diaz-Daiz et al., 2008).

In the same field of research, Sveiby (2001) distinguished nine basic knowledge transfers that create value to the organization, they are: between individuals, from individuals to the external structure, from the external structure to individuals, from individual's competence into the internal structure, from the internal structure to individual competence, within the external structure, from external to internal structure, from internal to external structure, and within internal structure. These nine knowledge transfers exist in most firms in spite of having legacy systems and culture that prevent the leverage (Sveiby, 2001).

In summary, KBV underlies this study. The purpose of this research is to examine the role of excellence by enhancing superior performance as a result of implementing TQM, ERP, and EO. It has been mentioned earlier that innovation is the main construct of excellence where it leads to organizational performance. Therefore, these variables used in this study have been underpinned theoretically by KBV.

\section{Literature Review}

\subsection{Organizational Performance}

In the literature of humanity and organizational studies, there are a great numerous researches that address organizational performance. This is because of the importance of performance in developing organizations and the implication of studies on organizational effectiveness and competitiveness.

In the management literature, organizational performance is considered as one of the most important construct in the field of strategic management and organizational studies (Combs, Crook, \& Shook, 2005). Therefore, in the last few years many academics and practitioners conducted a lot of researches on organizational performance for the purpose of understanding the processes, antecedents, and other factors that can enhance organizational outcomes (Jin \& Avery, 2008).

\subsubsection{Organizational Performance Definition}

It has been argued by Sink and Tuttle (1989) that the system of organizational performance is a complex relationship between six performance criteria: innovation, effectiveness, efficiency, productivity, quality, and profitability. Although, there is a bulk research work in the literature regarding organizational performance, but there is no agreement among researchers on the definition of organizational performance (Ford \& Schellenberg, 1982; Johannessen, Olaisen, \& Olsen, 1999). For example, Moullin (2007) defined organizational performance as a measure used by organizations to manage well their effectiveness, and deliver value to stakeholders and customers. Similarly, Antony and Bhattachatyya (2010) defined organizational performance as an instrument and measurement 
that used to evaluate and assess the successfulness of organizations to create and deliver value to their external and internal stakeholders.

\subsubsection{Public Organizational Performance}

In the public sector organization, the main purpose of performance management is to make performance, resources, and objectives clear; to integrate nonfinancial and financial information; to integrate budget cycle and policy; and to improve quality, accessibility, and information content of the information management (De Waal, 2010).

Performance in private and public organizations is different due to their objectives and core business. While public sector organizations intend to achieve good performance, quality, and customer satisfaction; private sector organizations intend to achieve profit and enhance customers. In other words, the main purpose of any public organization is to fulfill customers and society needs within its available budget (Dewhurst, Martinez-Lorente, \& Dale, 1999). In addition, goals and objectives in public sector organizations are more intangible in nature than in private sector organizations (Cinca et al., 2003).

In relation to public organization measurement, measuring performance in public organizations is an integral part in the whole management process in order to evaluate the extent of achieving the aimed strategic objectives, and to identify the major problems to solve them in the future (Kanji \& Sa, 2007).

\subsubsection{Measuring Organizational Performance}

Performance measurement is very important for organizational management effectiveness (Demirbag et al., 2006), and it is regarded and important aspect in management (Pongatichat \& Johnston, 2008). According to Deming, improvement of something cannot be without measuring that thing. Thus, organizational performance improvement needs some measurements to identify the extent of organizational resources effectiveness on business performance (Gadenne \& Sharma, 2002).

Traditionally, organizational performance has been measured by financial indicators that have weaknesses, therefore, some authors (Demirbag et al. , 2006) suggested and added some non-financial indicators to the existing traditional measurement tools. In relation to performance measurement definition, Neely et al. (2005) defined performance measurement as a set of metrics that used to quantify both efficiency and effectiveness of actions. The above mentioned financial measures such as profit, sales, debt, and return on investment, are not enough to face today's competitive in a business environment. Johnson (1983) and Kaplan (1984) argued that financial measures are not efficient for measuring organizational performance in the rapid change in the business environment. For this purpose, some other non-financial measures have been added. Nonfinancial measure such as creating value for customers, stakeholders, and society, has been greatly investigated because of their role in expectation and including of indicators of financial performance in the future (Kristensen \& Westlund, 2004).

At the present time, there are several systems that used to measure organizational performance such as Balanced Scorecard (BSC) and The Performance Prism. The first measurement has been created by Kaplan and Norton (1992), whether the other measurement created by Neely and Adams in 2000.

\subsection{Total Quality Management (TQM)}

In today's changing business environment, Total Quality Management (TQM) has become a major change that demands a transformation in the organization's culture, processes, strategic priorities, and beliefs among others (Motwani, 2001). In the literature, there is a bulk of research work about the role of TQM in enhancing and developing performance and gaining competitive advantage of the organization.

TQM is regarded as a holistic approach in managing organizations and concentrating on organizational objectives through improvement of productivity, quality, competitiveness, and meeting customers' needs (Pfau, 1989). The development of TQM passed in different phases, from quality by inspection, statistical quality control, and quality assurance to total quality management (Prybutok \& Ramasesh, 2005).

\subsubsection{Definition of Quality and TQM}

There are many definitions of quality in the literature. For examples, Deming (1986), Feigenbaum (1986), and Juran (1988) defined quality due to customer satisfaction, expectations, and needs. They focus on the concept of quality as "fitness for use". On the other hand, literature of quality management includes abundant definitions for TQM. For example, Pfau (1989) defined TQM as an approach for continuously improving of quality of service and the delivered goods in organizations through participating from all individuals. Similarly, Gao (1991) defined TQM as a philosophy of management that help organizations to generate efficiency and quality of goods and services through increasing satisfaction of customers and improving the quality of products and services. 
In relation to that, Zairi (1994) debated that the voices of the customer and processes are matched; therefore, creating a better planning, better external and internal focus, better design, protecting the strong area, and strengthening weak processes can be attained by TQM.

\subsubsection{TQM's Critical Success Factors}

Critical Success Factors (CSFs) are those critical areas inside organization to be implemented to achieve the vision, goals, and mission by examination and categorization their impacts (Oalkland, 1995). In the literature, numerous writers identified many CSFs that can affect the implementation of TQM whether positively or negatively. As examples for those writers, Salaheldin (2008) identified 24 CSFs in his study in Qatar. He divided his model into three levels: strategic, tactical, and operational.

In connection with that, Yusof and Aspinwell (2000) found that TQM implementation has several CSFs, they are: leadership, continuous improvement system, measurement and feedback, human resource development, education and training, improvement tools and techniques, supplier quality assurance system and processes, measurement and feedback, and work environment and culture. In addition the same contribution, Rahman (2001) in his empirical study in 53 Australian SMEs identified some CSFs for successful implementation of TQM, they are: leadership, strategy and planning, employee training and development, employee empowerment and employee involvement, information and analysis, and customer management.

\subsubsection{Total Quality Management (TQM) and Organizational Excellence}

TQM's core principles are to encourage business best practices that will satisfy customers, increase productivity, reduce cost, and enhance quality of output. Therefore, business excellence can be enhanced by practicing TQM principles in organizations (Lee, 2002).

The relation between TQM practices and organizational excellence has been investigated by many authors. For example, Sharma and Kodali (2008) reviewed 28 models, awards, and frameworks for the purpose of comparative analysis to identify elements of TQM. Their finding of their research is a framework of TQM elements of manufacturing excellence sustainability. In other words, TQM excellence is regarded as a fundamental criterion for achieving manufacturing excellence.

In the same vein of research, Lyons, Acsente, and Waesberghe (2008) examined how quality management and knowledge management can be integrated into the operational model to sustain excellence. They found that learning paths for quality implementation and integrated knowledge management can engage both workforce and leadership for using knowledge management tools.

In his contribution to the same field, Lee (2002) investigated how business excellence can be achieved through implementing best practices of TQM based on data collected from face-to-face and in-depth interviews of members who were responsible for leading the business to become winners of the Singapore Quality Award. He found that implementing of TQM practices can sustain organizations to achieve business excellence.

\subsubsection{Total Quality Management (TQM) and Organizational Excellence and Performance}

In the literature on quality management, there is a lot of research work that conducted the relationship between TQM and organizational performance (Corredor \& Goni, 2011). Most of these researches have confirmed that TQM adoption will eventually add value to all organization types (Sila \& Ebrahimpour, 2002). In addition, several studies showed that TQM is associated positively with performance outcomes, like financial performance and profitability (Cummings \& Worley, 1997); and human outcomes, like employee and customer satisfaction, and employee relations (Lawler et al., 1995).

The mediating role of TQM on the relationship between organizational performance and organization strategy has been studied by Feng, Prajogo, Tan, and Sohal (2006) based data collected from 194 senior and middle managers in Australian firms. Their result confirmed the partial mediating effect of TQM on the relationship between business strategy and organizational performance.

In the Chinese context, Lee (2004) in his empirical study investigated the impact of TQM implementation on the organizational performance in Chinese SMEs, based on data collected from 112 firms in China. He found a positive relationship between TQM and organizational performance in SMEs.

The effect of TQM on the organizational excellence is clear in the role of TQM principles to foster business practices that will enhance productivity, quality of output, satisfy customers, and reduce costs. In other words, TQM practices support organizations to enhance and increase business excellence (Lee, 2002). This relation has been approved by many writers, for example, Ioncia and Baleanu (2010) pointed out that EFQM Excellence Model principles have 
explicit and implicit relation to the basic principles of TQM. In addition, Lyons, Acsente, and Waesberghe (2008) examined how excellence can be achieved when integrating quality management and knowledge management in operational model and framework. They found that learning for implementing quality and integrated knowledge is important for engaging both workforce and leadership.

In the same vein, Lee (2002) investigated the effect of framework of best practices of TQM on business performance based on data collected from interviews of organization members who were in charge for leading their companies to be the winners of the Singapore Quality Award. His results are very beneficial for any organization that has a plan to implement TQM for the purpose of achieving business excellence.

Literature of quality management contains plenty of research that studied the relationship between TQM and organizational performance. For example, Yong and Wilkinson (1999) reviewed 15 researches where showed the positive and negative impact of TQM on performance, however they were conducted in different countries. Their conclusion was as a recommendation to implement fully TQM strategy to achieve organizational performance, i.e. TQM should be as an essential part of organizational operations.

Molina-Azorin, Tari, Claver-Cortes, and Lopez-Gamero (2009) argued that the development of quality management theory was based on three sources: the prescription of the quality gurus, the National quality awards, and measurement studies. Moreover, they found the successful implementation of TQM can lead and improve organizational performance.

Therefore, the following effects can be hypothesized.

\section{H1: TQM has a significant effect on the organizational excellence.}

\section{H2: TQM has a significant effect on the organizational performance.}

\subsection{Enterprise Resource Planning (ERP)}

Enterprise Resource Planning (ERP) is considered as one of the major shifts in the last two decades that increase productivity and efficiency, and attract many attentions in the last few years (Elbanna, 2006). This is because of its ability to reduce costs, increase profit, competing in a global market, and establishing competitive advantage.

D'Aquila, Shepherd, and Friscia (2009) pointed out that ERP's global market revenue were $65 \$$ billion in 2008 , $61 \$$ billion in 2009 , and estimated to be $65 \$$ billion in 2010 . Structure of ERP systems has been developed from the original fundamental structure in the 1950s and 1960s when computers have turned to business (Moller, 2005).

The ERP system has been considered as a complex system that based on integration of business processes into the material, automate information flow, and financial resources by using a common database (Kumar, Maheshwari, \& Kumar, 2002).

According to Huang and Palvia (2001), ERP implementation is affected by two categories factors: internal/organizational and environmental/national where each of them has five variables, they are: economy and economic growth, infrastructure, IT maturity, computer culture, business size, BPR experience, manufacturing strengths, government regulations, management commitment, and regional environment.

Davenport (1998) argued that ERP systems are different from other normal software in terms of uniqueness and integration features. Therefore, in the last few years, organizations have implemented ERP systems by using software packages from different vendor, such as SAP, Oracle, and PeopleSoft (Summer, 2005). At a point of time, the ERP application package is regarded as a dream that come real when information flow through the integration of sections in organizations such as supply chain, human resources, customer relationships, and accounting (Davenport, 2002).

\subsubsection{Definition of Enterprise Resource Planning (ERP)}

However, there is an extensive work in the literature of the ERP systems. However, there is no agreed upon definition of ERP system among researchers. ERP was defined differently due to the role and approach that ERP plays in organizations. As example for these definitions, Tarn et al. (2002) defined ERP as an application packages that are interrelated and integrated to help different functions of business such as inventory management, manufacturing, human resource management, financial management, and accounting. Another definition has been emerged by Scalle and Cotteleer (1994), ERP is an information system that involves all business aspects such as sales distribution, purchasing, production planning, customer service, finance, and manufacturing.

Similarly, Davenport (2002) defined ERP as a developed technological system that integrate information within organizations such as finance and accounting, supply chain, customer relationships, and human resource. According 
to Fang and Lin (2006), ERP systems are commercial software that is standard and customized applications that integrate solutions for business processes and the major functions in organizations.

\subsubsection{Benefits of Enterprise Resource Planning (ERP)}

Benefits of ERP are many, but cannot be achieved only after its implementation (Hsu \& Chen, 2004). For example, Mabert, Soni, and Venkartaramanan (2003) identified several tangible benefits of ERP such as improve order cycle, decrease financial close cycle, reduce direct operating cost, improve on-time delivery, lower inventory level, and improve interaction with customers. In contrast to legacy traditional systems, that they are weak and limited in terms of technological changes, transforming components to another framework, maintenance cost, and flexibility; where ERP could overcome these limitations (Gupta \& Bhatia, 2005).

In relation to the technical and operational benefits, Sandoe et al. (2001) stated that there are two main motivations towards ERP systems, technical and operational. Technical aspect benefits can be found in creating a more flexible environment, improving their own goals and strategies, poor performance, inefficient processes, and inconsistent business processes.

\subsubsection{Critical Success Factors of Enterprise Resource Planning (ERP)}

ERP's Critical Success Factors (CSFs) have been studied by many researchers. For example, Yang, Ting, and Wei (2006) identified six dimensions for measuring ERP performance from the system user's perspective, they are: information quality, users' satisfaction, system efficiency, system functions, use attitude, and system quality.

In connection with that, Shad, Chen, and Azeem (2011) identified five critical factors that affect ERP implementation to success or failure. These factors are business process re-engineering, effective usage of process database, technical selection of quality consultant, architecture choices, and education on new business processes.

Additionally, Al-Mashari et al. (2003) identified some factors that impact ERP implementation such as the ERP package selection, project management, cultural and structural change, training and education, system testing, process management, system integration, communication, and legacy system management. Moreover, Umble et al. (2003) found nine critical success factors, they are: clear understanding of strategic goals, excellent implementation team, multi-site issues, change management, focused performance measures, excellent project management, education and training, commitment from top management, and data accuracy.

3.3.4 The Relationship between Enterprise Resource Planning (ERP) and Organizational Excellence and Performance

The relationship between ERP and organizational performance has attracted many writers in the last few years. ERP implementation has been done to improve performance of an organization and increase efficiency and effectiveness, and finally increase and improve financial performance (Kallunki, Laitinen, \& Silvola, 2011). Therefore, ERP can lead organizations towards creating new generic processes which will be measured as the source of competitive advantage (Davenport, 1998).

Previous research about the relationship between ERP systems and organizational performance showed conflicting results (Kang, Park, \& Yang, 2008). Some found that investment in ERP systems can improve overall organizational performance (Bendoly \& Kaefer, 2004), others argued that ERP systems only provide performance in specific areas (Evan \& Bragg, 1997; Laughlin, 1999), whereas others pointed out that ERP systems can affect performance negatively due to some critical success factor such as education, training, culture, and top management commitment and support.

Hunton, Lippincott, and Rech (2003) examined the impact of ERP on organizational performance for adopters and nonadopters of ERP system. Their finding displayed a significant difference in financial performance of non-adopters decreased over time whereas stable for adopters organizations. In connection with that, Peffers and Dos Santos (1996) found a positive relationship between innovative IT such as ERP and organizational performance.

Similarly, Florescu, Ionescu, and Tudor (2010) examined the effect of IT to improvement of organizational performance. They found that ERP can help organizations to improve their performance if they gather it with other sources such as human resources and capacity, the team's structure, and monitoring of performance. In connection with that, Nicolaou and Bhattacharya (2006) investigated the effect of ERP over post implementation time can affect and improve the financial performance in long-run.

Based on the past research and the theoretical arguments, the following hypotheses can be introduced as guidelines for future research work endeavors. 


\section{H3: ERP systems have a significant effect on the organizational excellence.}

\section{H4: ERP systems have a significant effect on the organizational performance.}

\subsection{Entrepreneurial Orientation (EO)}

Entrepreneurship has become more significant in today's complex universal economy, to acquire successfulness and sustain competitive advantage and organizational performance (Covin \& Slevin, 1986; Wiklund \& Shepherd, 2003; Zahra, 1986). In relation to performance, entrepreneurship writers and researchers in both the popular press and scholarly literature honored the importance of entrepreneurial activity's role and positively suggested the relationship between performance and entrepreneurship (Lumpkin \& Dess, 2001).

Lumpkin and Dess (1996) recognized the distinction between entrepreneurial orientation and entrepreneurship by proposing that the entrepreneurial orientation process answer the question how projects are undertaken, whereas entrepreneurship refers to the content of entrepreneurial decision by answering what is undertaken.

\subsubsection{Definition of Entrepreneurship}

The entrepreneurship term has been used for many decades, but there is a little agreement about its definition (Williams et al., 2010). In the literature several definitions have explained the meaning of entrepreneurship such as creation of innovation, creation of growth, creation of the enterprise, the creation of value, and the creation of employment (Morris et al., 2008).

According to Ireland et al. (2001), entrepreneurship is a context-dependent social process that originates wealth through individuals and teams by fetching together the unique resources to have the advantage of marketplace opportunities. From their point of view, Slevin and Covin (1990) considered entrepreneurship as intrapreneurship or organizational behavior, and entrepreneurial orientation as methods, practices, process, decision making, and operating philosophy that upper management use their abilities to transform their organizations into entrepreneurial business entities.

\subsubsection{Entrepreneurial Orientation (EO)}

In the literature of entrepreneurship, there are different definitions for the entrepreneurial orientation construct. For example, Frank, Kessler, and Fink (2010) defined EO as an organizational strategic orientation of grasping the specific entrepreneurial aspects of practices, methods, and decision making. In addition, Zahra and Covin (1995) defined EO as the potential tools inspiriting established organizations, where can be gained through innovation, proactiveness, and risk taking.

The three dimensions of EO have been suggested earlier by Miller (1983) and other two dimensions namely, aggressiveness and autonomy, have been added later by Lumpkin and Dess (1996). However, the majority of the research conducted regarding EO have used the three dimensions namely Innovativeness, proactiveness and risk taking to measure the EO construct (Wiklund, 1999).

Innovativeness is related to giving support to novelty, creative processes, and development and growth of new ideas through experimentation (Lumpkin and Dess, 1996). It is more related to increasing the probability that an organization will attain the advantage of the first-mover (Wiklund, 1999). Therefore, innovativeness has become the most significant factor the employed to characterize entrepreneurship, and contributes to the profitability and growth of entrepreneurial organizations (Covin \& Miles, 1999; Covin \& Wales, 2010).

Proactiveness is the willingness of organizations and their ability to expect new development as fast as possible to have the advantage of the first-mover in relation to other competitors, instead of waiting for imitating of new development and then react according to them (Kessler, \& Fink, 2010). According to Lumpkin and Dess (2001) proactiveness is an approach for seeking opportunities of new services and products and responding quickly to customers' anticipation and demand.

Risk-taking is the degree that managers are willing to have resource commitment to emerging opportunities where there is a reasonable chance of costly failure Miller and Friesen (1978). Moreover, it has been argued by Caruana, Ewing, and Ramaseshan (2002) that innovation cannot be existed without risk taking. Therefore, risk taking is considered as the most important factor of EO where it is usually used to demonstrate entrepreneurship (Osman et al., 2011).

\subsubsection{Entrepreneurial Orientation (EO) and Organizational Excellence and Performance}

Many researchers studied the relationship between EO and organizational performance. However, there is a dearth of research examining the effect of EO on organizational excellence. Most of the studies on EO are focusing on three 
dimensions of EO, i.e. innovativeness, proactiveness, and risk taking. For example, Rauch et al. (2009) investigated this relationship using meta-analysis approach. Their result concluded the importance of involving and assessing more additional moderators when examining the relationship between EO and organizational performance.

In connection with that, Lumpkin and Dess (2001) examined the moderating effect of industry life cycle and environment on the relationship between EO and organizational performance. They found that proactiveness and aggressiveness have different impact on organizational performance, where proactiveness was related positively to organizational performance, but aggressiveness was weakly associated performance.

Additionally, Caruana, Ewing, and Ramaseshan (2002) examined the impact of centralization and environmental challenges on the EO-performance relationship. Their findings approved that the environmental variables affect positively the performance, and EO is positively associated with organizational performance in public organizations.

In their contribution to the same field, Jogaratnam and Tse (2006) examined the EO structure and performance within the Asian hotel industry context. Their results showed that the entrepreneurial strategic posture is associated positively with organizational performance, and organic structure is negatively associated with organizational performance.

Altinay and Altinay (2004) examined the impact of organizational structure on EO and expansion of performance. Their study showed that EO is a significant organizational characteristic for both entrepreneurship and literature of international management.

In their contribution to the same stream of research, Wiklund and Shepherd (2005) suggested a configurational approach to study the effect of EO in business performance. They gathered data from 413 Swedish firms and found that combining of EO the configurational approach demonstrate variance in performance over main-effect-only model and contingency model.

Davis et al. (2010) investigated the moderating role of manager power such as expert, prestige, and structural power on the relationship between EO and organizational performance. Their results showed that there is a positive influence of manager power characteristic on the relationship between EO and organizational performance. In addition to that, Richard, $\mathrm{Wu}$, and Chadwick (2009) studied the role of CEO on the relationship between EO and organizational performance in UAS banks. They found that CEO industry tenure positively moderates the relationship between EO and organizational performance.

Thus, the following hypotheses should be introduced for further empirical examination

\section{H5: Entrepreneurial Orientation has a significant effect on the organizational excellence.}

\section{H6: Entrepreneurial Orientation has a significant effect on the organizational performance.}

\subsection{Organizational Excellence}

The highest rank of evaluation is denoted by the word "excellence". It is used to evaluate the highest rank for achievements by people or organizations. Dahlgaard-Park (2009) pointed out that it is difficult to realize when you will gain excellence if you do not understand what it is. In the literature of humanity studies, the word "excellence" is always preceded by or related with "business" or "organizational", however the two words leading to the same meaning with the difference that "organizational excellence" is more used with public sector, and "business excellence" with private sector organizations (McAdam, 2000).

In the present time, many organizations are looking for organizational excellence, but unfortunately most of them failed to have it because of the misunderstanding what is the meaning of excellence (Dahlgaard, 2003). According to Antony and Bahattacharyya (2010) that the organizational excellence concept in academic research is first originated from Peter and Waterman (1982). They also concluded that organizational excellence helps managers in their organizations to evaluate and differentiate the level of success and achievement better than the organizational performance measurement.

\subsubsection{Definition of Excellence}

In literature, the word excellence has different definitions. For example, Hillman (1994) defined excellence assessment as the process of evaluating an organization against a model of continuous improvements to understand what has been accomplished and what more improvements it needs. Another definition came from the European Foundation for Quality Management (EFQM guidelines, 1999) that excellence is a prominent practice in managing and achieving results in an organization based on nine basic concepts, viz result orientation, leadership and 
constancy of purpose, continuous learning, public responsibility, management by facts and process, partnership development, innovation and improvement, customer focus, and people development and involvement.

The word "excel" has been defined by the American Heritage dictionaries (1992), as "to do or be better than; surpass, to show superiority, surpass others". Moreover, the construct excellence is derived from the Latin word "Execeller" which refers to "to ascend" (Attafar, Forouzan, \& Shojaei, 2012). They argued that the meaning of excellence in literature is related to the author's point of view, such as excellence means quality (Waterman, 1992), proportionality for use ((Juran and Gryna, 1988), and value (Feigenbaum, 1983), perfectness, accuracy, and absoluteness (Attafar, Forouzan, \& Shojaei, 2012).

In connection with that, Moghadami (2005) pointed out that excellence organization should have the following characteristics: customers, employees, leadership, capital owners, learning, future generation, globalization, change or transformation, and suppliers and strategic partners. In relation to that, Eisakhani (2008) determined seven characteristics of excellence organizations like, ambition purposes, strategic thinking, leadership, technology, processes, perspective and mission, and organization planning. Similarly, Riahi (2005) pointed out twelve characteristics for excellence organizations such as, innovation and learning, foreseeing and inspired leadership, being flexible and responsive, paying attention to beneficiaries' needs, effective management system, development and preserving cooperation, using short-term, medium-term and long-term programs, employees participation, clarification and responsiveness, focusing on potential demands of customers, paying attention to process.

\subsubsection{Business and Organizational Excellence Models}

Organizational or business excellence models are those tools or measurements that help organizations to measure and evaluate the degree of being excellent organizations (Attafar, Forouzan, \& Shojaei, 2012). In addition, these models help organizations to contrast and compare themselves with competitors' best practices and lead encouragement for clarification, recognition, self-evolution, and explaining attitudes which related to results of performance (Ghorbani $\&$ Nouri, 2005).

Due to the advantages of using organizational excellence models, Salekzamani (2006) determined the following advantages: organizational excellence models help organizations to improve applications of organizational performance and their results, tools for perception and performance management, help organizations in their direction of strategic planning, and help organizations to share information and facilitate communications by using applications of best practices.

The following models are the most well-known organizational excellence models:

1) Deming Award Model in Japan (1951): Deming was the person who reformed the Japanese economy after the $2^{\text {nd }}$ world war (Petersen, 1990). Deming's approach for excellence gained energy in the early of the 1980s. Therefore, Japan established award called "The Deming Prize" that refers to the award of Japan's Quality Award (Rungtusanatham, Ogden, and $\mathrm{Wu}, 2003$ ). According to them, Deming model has fourteen points for organizational improvement, they are: Create constancy of purpose, Adopt the new philosophy, Cease dependency on mass inspection, End the practice of awarding business on the basis of price tag alone, Improve constantly and forever the system of service and production, The job training should be instituted, Institute leadership, Drive out fear, Break down the barriers between departments, Eliminate slogans, exhortations, and targets for the workforce, Eliminate work standards, management by objective, substitute leadership, and eliminate management by numeric goals, Remove barriers that plunder the hourly worker of his right to pride of workmanship, Institute strong program of education and self-improvement, and Transformation should be accomplished by everyone in the company.

2) Peters and Waterman's model (1982): Peters and Waterman (1982) choose 500 companies from 53 industrial scopes. They accomplished eight characteristics of successful companies, they are: Bias for action, Close to the customer, Autonomy and entrepreneurship, Productivity through people, Hands-on, value-driven, Stick to the knitting, Simple form, lean staff, and Simultaneous loose-tight.

3) Malcolm Baldrige Model (1987): in 1987, USA congress created the Malcolm National Quality Award (MNQA) to acknowledge quality and performance, and enhance excellence in American firms (Dejong, 2009). There are seven categories of MIBNQA mentioned by Davis, Marcos, and Stadning (2005), as follows: Leadership, Strategic planning, Customer and market focus Information and Analysis, Human resource management focus, Process management, and Business results.

4) European Excellence Model (EFQM) (1991): EFQM has been established to help organizations measure their level of performance. It has nine criteria that used to measure this level, they are: Leadership, Policy and 
Strategy, People, Partnerships and Resources, Process, Customers Results, People Results, Society Results, and Key Performance Results.

5) Kanji's Leadership Excellence: it is an instrument to measure the level of business performance by a leadership construct (Oakland \& Tanner, 2008). This model is designed to be used in both private and public organizations. The pyramid model has been examined the excellence model (Kanji, 1998).

6) Malaysian Total Performance Excellence Model: Hussain et al. (2001) the MTPEM consists of the following constructs: leadership, change management, culture and values, strategy and objectives, resource management, best practices, innovation, employee satisfaction customer, community and stakeholder focus, productivity, and total Performance.

\subsubsection{Leadership and Organizational Excellence}

As we can see above that most of excellence models considered leadership as the most critical factor that enhance higher performance for organizations. Therefore good leadership can be regarded as the key to organizational success and superior performance (Pinar \& Girard, 2008). In connection to that, Darling and Nurmi (1995) argued that organizational excellence can be accomplished through development and implementation of leadership strategies. Furthermore, Dahlgaard-Park (2009) indicated that management without leadership cannot generate and create excellence. She added that organizational excellence initiated by building leadership which means developing leaders through education and training to have the capability to gain competencies. In addition, organizations that attempt to achieve excellence should have a harmonized relationship between leaders and followers and work as a team.

\subsubsection{Organizational Excellence and Organizational Performance}

The relationship between organizational performance and organizational excellence is interrelated where one of them leads directly to the other. In some cases organizational performance in organizations will be followed by or lead to excellence. According to EFQM, organizations that achieve 60 per cent in their performance are considered excellent organizations. Moreover, excellence existing models look at excellence as an outstanding level of performance (Antony \& Bhattacharyya, 2010).

In their effort to examine the relationship between organizational performance and organizational excellence, Antony and Bhattacharyya (2010) examined this relationship based on data collected from 407 respondents in SMEs in India. Their result suggested that organizational excellence and performance can be measured by consolidating variables of performance. In other words, organizational excellence could be calculated based on the relationship between performance variables.

In relation to that, Ooncharoen and Ussahawanitchakit (2008) examined the relationship between business performance and organizational excellence of the Hotel business in Thailand based on data collected by the questionnaire instrument from 278 hotels. They found that organizational excellence has a significant positive effect on performance.

In their contribution to the same field, Kiitam and Tammaru (2012) studied the impact of application of excellence models (EM) on organizational performance. They concluded that there is a positive impact of the use of excellence models in different dimensions (sustainability, financial performance, and excellence) on organizational performance if these models are implemented appropriately.

In connection with the same stream of interest, the relationship between excellence models and organizational performance, Ciptono (2005) investigated the link between operational excellence, Deming's principles, company performance, and world-class company based on data collected from 140 strategic units in 49 gas and oil companies in Indonesia. His results approved that there is a positive significant effect on company performance, and organizational performance of the company can be enhanced by excellence models such as Deming's excellence model.

Based on the above arguments and other supporting ones, the following hypothesis can be proposed.

H7: The organizational excellence has a significant effect on the organizational performance.

H8: The organizational excellence mediates the relationship between TQM and organizational performance.

H9: The organizational excellence mediates the relationship between ERP systems and organizational performance

H10: The organizational excellence mediates the relationship between $\mathrm{E} O$ and organizational performance 


\section{Proposed Research Framework}

Based on a thorough review of the literature reveals that the effects of TQM, ERP, and EO on the Organizational Performance are still inconsistent. To resolve this inconsistency, this study suggested that the organizational excellence construct could explain the mechanism through which this effect could be made effective. The proposed framework could be the guidelines for empirical research aiming to explore the determinants of organizational performance especially in the fast paced technological era.

$<$ Insert Figure 1 Here $>$

\section{Conclusion and Recommendations for Future Research Directions}

In conclusion, this paper attempted to expand the boundaries of the knowledge pertaining to the performance implications of TQM, ERP and EO. The research model resulted from this study provides an original and unique theoretical framework which could be a reference model to examine the effectiveness of the total quality management, enterprise resource planning and entrepreneurial orientation. The originality of this research framework could be due to the introduction of organizational excellence to explain the potential effect of TQM, ERP and EO on overall organizational performance. This framework was proposed to resolve the inconclusive results regarding the effects of TQM, ERP and EO on the organizational performance and to explain why these strategies may fail in producing the desired results.

In general, this research framework could be a guideline for future empirical research further explain the effect of knowledge based organizational capabilities and the overall organizational performance.

Apart from the potential importance of organizational excellence in explaining the effect of TQM, ERP and EO on organizational performance, the entrepreneurial culture should be considered as an important factor in these causal relationships. Meaning that, the effectiveness of these strategies can be measured through their ability to produce an organizational culture that encourages the innovation and tolerate the failure as the way of learning and improvement. If such culture is not developed, there will be a huge resistance for any improvement that incurs a risk. In other words, in order for any organization to achieve the excellence and subsequently achieve high record organizational performance, it has to be open for any technologically driven innovation and able to foresee business opportunities by creating an entrepreneurial organizational culture.

\section{References}

Al-Mashari, M., Al-Mudimigh, A., \& Zairi, M. (2003). Enterprise resource planning: a taxonomy of critical factors. European Journal of Operational Research, 146, 352-64. http://dx.doi.org/10.1016/S0377-2217(02)00554-4

Al-Swidi, A. K., \& Mahmood, R. (2011a). Fostering the Performance of Banks through Total Quality Management (TQM) Practices: A Bank Branches Perspective. European Journal of Social Sciences, 19(2), 268-285.

American Heritage Dictionary. (1992). Delta, New York, NY.

Andersen, J. (2010). A critical examination of the EO-performance relationship. International Journal of Entrepreneurial Behaviour \& Research, 16(4), 309-328. http://dx.doi.org/10.1108/13552551011054507

Antony, J. P, \& Bhattacharyya, S. (2010). Measuring organizational performance and organizational excellence of SMEs - Part 2: an empirical study on SMEs in India. Measuring Business Excellence, 14(3), 42-52. http://dx.doi.org/10.1108/13683041011074209

Attafar, A., Forouzan, B., \& Shojaei, M. (2012). Evaluation of Organizational Excellence Based on Peters and Waterman's Model in Tuka Steel Investment Holding. American Journal of Scientific Research, (50), 119-137.

Barney, J. B. (2002). Gaining and Sustaining Competitive Advantage (2nd ed.). Upper Saddle River, NJ: (Prentice Hall).

Barney, J.B. (1991). Firm resources and ( ${ }^{8}$ rm competitive advantage. Journal of Management, 17, 99-120. http://dx.doi.org/10.1177/014920639101700108

Bendoly, E., \& Kaefer, F. (2004). Business Technology Complementarities: Impacts of the Presence and Strategic Timing of ERP on B2B E-commerce Technology Efficiencies. Omega, 32(5), 395-406. http://dx.doi.org/10.1016/j.omega.2004.02.004

Caruana, A., Ewing, M.T., \& Ramaseshan, B. (2002). Effects of some environmental challenges and centralization on the entrepreneurial orientation and performance of public sector entities. The Service Industries Journal, 22(2), 43-58. http://dx.doi.org/10.1080/714005076 
Cinca, C. S., Molinero, C. M., \& Queiroz, A. B. (2003). The Measurement of Intangible Assets in Public Sector Using Scaling Techniques. Journal of Intellectual Capital, 4(2), 249-275. http://dx.doi.org/10.1108/14691930310472857

Collis, D. J. (1994). Research note: How valuable are organizational competence. Strategic Management Journal, 15, 143-152. http://dx.doi.org/10.1002/smj.4250150910

Combs, J. G., Russell Crook, T., Shook, C. L., David J., \& Ketchen, J. A. D. D. B. (2005). The Dimensionality of Organizational Performance and its Implications for Strategic Management Research. Research Methodology in Strategy and Management, 2, 259-286. http://dx.doi.org/10.1016/S1479-8387(05)02011-4

Conner, K., \& Pralahad. (1996). A Resource-based Theory of the Firm: Knowledge vs. Opportunism. Organization Science, 7(5), 477-501. http://dx.doi.org/10.1287/orsc.7.5.477

Cornwall, J.R., \& Perlman, B. (1990). Organizational Entrepreneurship. Irwin: Homewodd.

Covin, J. G., \& Slevin, D. P. (1991). A conceptual mode of entrepreneurship as firm behavior. Entrepreneurship Theory and Practice, (Fall), 7-25.

Covin, J. G., \& Slevin, D. P. (Eds.). (1986). The Development and Testing of an organizational level Entrepreneurship Scale. Wellesley,MA: Babson College.

Covin, J. G., \& Wales, W. J. (2010). The Measurement of Entrepreneurial Orientation. Paper presented at the Annual Meeting of the Academy of Management (AoM), Montreal, QC.

Covin, J., \& Miles, M. (1999). Corporate entrepreneurship and the pursuit of competitive advantage. Entrepreneurship: Theory \& Practice, 23(3), 47-63.

Cummings, T. G., \& Worley C. G. (1997). Organizational development and change. South- Western College Publishing, Ohio.

D’Aquila, M., Shepherd, J., \& Friscia, T. (2009). The global enterprise applications software market forecast update 2009-2010. AMR Research.

Dahlgaard-Park, S. M. (2009). Decoding the code of excellence - for achieving sustainable excellence. International Journal of Quality and Service Science, 1(1), 5-28. http://dx.doi.org/10.1108/17566690910945840

Darling, R. John, \& Nurmi, R. (1995). Downsizing the Multinational Firm: Key Variables for Excellence. Leadership \& Organizational Development Journal, 16(5), 22-28. http://dx.doi.org/10.1108/01437739510088509

Davenport, H. T. (2002). Putting the Enterprise into the Enterprise System. Harvard Business Review, 9(3), 14.

Davenport, T.H. (1998). Putting the Enterprise into the Enterprise System. Harvard Business Review, 121-131.

Davenport, T.H., \& Brooks, J.D. (2004). Enterprise systems and the supply chain. Journal of Enterprise Information Management, 17(1), 8-19. http://dx.doi.org/10.1108/09576050410510917

Davis, J. L., Bell, R. G., Payne, G. T., \& Kreiser, P. M. (2010). Entrepreneurial Orientation and Firm Performance: The Moderating Role of Managerial Power. American Journal of Business, 25(2), 41-53. http://dx.doi.org/10.1108/19355181201000009

Davis, R. A., Marcos, S., \& Stading, G. L. (2005). Linking firm performance to the Malcolm Baldrige National Quality Awrad implementation effort using multiattribute utility theory. Managerial Finance, 31(3), 19-33. http://dx.doi.org/10.1108/03074350510769541

De Waal, A.A. (2010). Characteristics of high performance organizations. Manuscript submitted for publication.

Dean, J.W., \& Bowen, D.E. (1994). Management theory and total quality: improving research and practice through theory development. The Academy of Management Journal, 19(3), 392-418.

Decarolis, D., \& Deeds, D. (1999). The Impact of Stocks and Flows of Organizational Knowledge in Firm Performance: An Empirical Investigation of the Biotechnology Industry. Strategic Management Journal, 20, 953-968. http://dx.doi.org/10.1002/(SICI)1097-0266(199910)20:10<953::AID-SMJ59>3.0.CO;2-3

Dejong, D. J. (2009). Quality improvement using the Baldrige Criteria for organizational Performance Excellence. Am J Health-Syst Pharm, 66, 1031-1033. http://dx.doi.org/10.2146/ajhp080450

Deming, W. E. (1986). Out of crisis. Cambridge, MA: Massachusetts Institute of Technology Press. 
Demirbag, M., Koh, S. C. L., Tatoglu, E., \& Zaim, S. (2006). TQM and market orientation's impact on SMEs' performance. Industrial Management \& Data System, 106(8), 1206-1228. http://dx.doi.org/10.1108/02635570610710836

Dewhurst, F., Martinez-Lorente, A., \& Dale, B. (1999). TQM in public organisations: an examination of the issues. Managing Service Quality, 9(4), 265-273. http://dx.doi.org/10.1108/09604529910273210

Diaz-Daiz, N., Aguir-Diaz, I., \& DeSaa-Perez, P. (2008). The Effect of Techmological Knowledge Assets on Performance the Innovation Choice in Spanish Firms. Research Policy, 37, 1515-1529. http://dx.doi.org/10.1016/j.respol.2008.06.002

Duobiene, J., \& Pundziene, A. (2007). Development OF Entrepreneurial Organizational Culture. Economics and Management.

EFQM (European Foundation for Quality Management). (1999). The Excellence Model, EFQM, Brussels.

EFQM. (1999). Self-assessment Guidelines for Companies. European Foundation for Quality Management, Brussels, Belgium.

Elbanna, A. R. (2006). The construction of the relationship between ERP and the organization through negation. Processing of the European Conference of Information Systems (ECIS), Goteborg. ProQuest Database.

Escrig-Tena, A. B. (2004). TQM as a competitive factor: A theoretical and Empirical Analysis. International Journal of Quality \& Reliability Management, 21(6), 612-637. http://dx.doi.org/10.1108/02656710410542034

Evans, M., \& Bragg, S. (1997). Ovum Evaluates ERP for Manufacturers. Ovum' 1997 Report.

Fang, M., \& Lin, F. (2006). Measuring the Performance of ERP System-from the Balanced Scorecard Perspective. The Journal of American Academy of Business, 10(1), 256-263.

Feigenbaum, A. V. (1983). Total quality control. New York: McGraw-Hill.

Feigenbaum, A.V. (1986). Total quality control (3rd ed.). New York: McGraw-Hill

Feng, J., Prajogo, D. I., Tan, K. C., \& Sohal, A. S. (2006). The impact of TQM practices on performance: A comparative study between Australian and Singaporean organizations. European Journal of Innovation Management, 9(3), 269-278. http://dx.doi.org/10.1108/14601060610678149

Ford, J. D., \& Schellenberg, D. A. (1982). Conceptual Issues of Linkage in the Assessment of Organizational Performance. The Academy of Management Review, 7(1), 49-58.

Frank, H., Kessler, A., \& Fink, M. (2010). Entrepreneurial Orientation and Business Performance - A Replication Study. Schmalenbach Business Review, 62, 175-198.

Gadenne, D., \& Sharma, B. (2002). An inter-industry comparison of quality management practices and performance. Managing Service Quality, 12(6), 394-404. http://dx.doi.org/10.1108/09604520210451876

GAO. (1991). Report to the House of Representatives on management practices: US companies improve performance through quality efforts. United States General Accounting Office, National Security and International Affairs Division, Washington, DC.

Ghorbani, M., \& Nouri, M. (2005). Organizational excellence in the governmental sector. Journal of Administrative change, (47).

Gibb, A. A. (2000). Corporate Restructuring and Entrepreneurship: What can large organizations learn from small?. Entrepreneurship and Innovation Management Studies, 1(1).

Grant, R. (1996). Prospering in Dynamically-competitive Environments: Organizational Capability as Knowledge Integration. Organization Science, 7(4), 175-183. http://dx.doi.org/10.1287/orsc.7.4.375

Grant, R.M., Shani, R., \& Krishnan, R. (1994). TQM's challenge to management theory and Practice. Sloan Management Review, 25-35.

Gupta, P. M., \& Bhatia, D. (2005). Reworking with a legacy financial accounting system. Lessons from pharma company. Interfaces, 30(3), p4

Hillman, G.P. (1994). Making self assessment successful. The TQM Magazine, 6(3), 29-31. http://dx.doi.org/10.1108/09544789410057863 
Hsu, L., \& Chen, M. (2004). Impacts of ERP system on the integrated-interaction performance of manufacturing and marketing. Industrial Management \& Data Systems, 104(1), 42-55. http://dx.doi.org/10.1108/02635570410514089

Huang, Z., \& Palvia, P. (2001). ERP implementation issues in advanced and developing countries. Business Process Management Journal, 7(3), 276-284. http://dx.doi.org/10.1108/14637150110392773

Hunton, J.E., Lippincott B., \& Reck J.L. (2003). Enterprise resource planning systems: comparing firm performance of adopters and nonadopters. Int J Account Inf Syst, 4, 165-184. http://dx.doi.org/10.1016/S1467-0895(03)00008-3

Hussain, N., Abdullah, M., Idris, F., \& Mohd Sagir, R. (2001). Total Performance Excellence Model. Total Quality Management, 12(7\&8), 928-938.

Irani, Z., \& Love, P.E.D. (2001). The propagation of technology management taxonomies for evaluating investments in information systems. Journal of Management Information Systems, 7(3), 161-77.

Ireland, R. D., Mitt, M. A., Camp, S. M., \& Sexton, D. L. (2001). Integrating Entrepreneurship Actions and Strategic Management Actions to Create Firm Wealth. Academy of Management Executive, 15(1), 49-63. http://dx.doi.org/10.5465/AME.2001.4251393

Jha, V. S., \& Joshi, H. (2007). Relevance of Total Quality Management (TQM) or business Excellence Strategy Implementation for Enterprise Resource Planning (ERP) - A Conceptual Study.

Jing, F. F., \& Avery, G. C. (2008). Missing Links in Understanding the Relationship between Leadership and Organizational Performance. International Business \& Economics Research Journal, 7(5), 67-78.

Jogaratnam, G., \& Tse, E.C. (2006). Entrepreneurial orientation and the structuring of organizations - Performance evidence from the Asian hotel industry. International Journal of Contemporary Hospitality Management, 18(6), 454-68. http://dx.doi.org/10.1108/09596110610681502

Johannessen, J. A., Olaisen, J., \& Olsen, B. (1999). Strategic Use of Information Technology for Increased Innovation and Performance. Information Management and Computer Security, 7(1), 5-22. http://dx.doi.org/10.1108/09685229910255133

Juran, J. M. (1988). Juran on planning on quality. New York: Free Press.

Juran, J.M., \& Gryna, F.M. (1988). Juran's Quality Control Handbook (4th ed.). McGraw-Hill, New York, NY.

Kallunki, J., Laitinen, E. K., \& Silvola, H. (2011). Impact of enterprise resource planning systems on management control systems and firm performance. International Journal of Accounting Information Systems, 12, 20-39, http://dx.doi.org/10.1016/j.accinf.2010.02.001

Kanji, G., \& Sá, P. (2007). Performance measurement and business excellence: the reinforcing link for the public sector. Total Quality Management \& Business Excellence, 18(1-2), 49-56. http://dx.doi.org/10.1080/14783360601043096

Kanji, G.K. (1998). Measurement of business excellence. Total Quality Management, 9(7), 633-643. http://dx.doi.org/10.1080/0954412988325

Kaplan, R. (1984). The Evolution of Management Accounting. The Accounting Review, LIX(3), 390-418.

Kaplan, R.S., \& Norton, D.P. (1992). The balanced scorecard \pm measures that drive Performance. Harvard Business Review, January-February, 70-79.

Kiitam, A., \& Tammaru, T. (2012). Impact of Application of Excellence Models on Organizational Performance. $8^{\text {th }}$ International Daaam Baltic Conference, Industrial Engineering.

Kumar, V., Maheshwari B., \& Kumar, U. (2002). Enterprise Resource Planning Systems Adoption Process: A Survey of Canadian Organizations. International Journal of Production Research, 40, 509-523. http://dx.doi.org/10.1080/00207540110092414

Kuratko, D. F., \& Welsch, H. P. (2004). Strategic Entrepreneurial growth (2nd ed.). Ohio: Thomson, South-Western.

Laughlin, S. (1999). An ERP game plan. Journal of Business Strategy, 20(1), 32. http://dx.doi.org/10.1108/eb039981

Lawler, E., Ledford, G., Mohman, S., \& Tenkasi (1995). Total quality management: Practice and outcomes in the largest US firms. Employee Relations, 17(3), 26-41. http://dx.doi.org/10.1108/01425459510086866

Lee, C. Y. (2004). TQM in small manufacturers: an exploratory study in China. International Journal of Quality \& Reliability Management, 21(2), 175-197. http://dx.doi.org/10.1108/02656710410516970 
Lee, P. (2002). Sustaining business excellence through a framework of best practices in TQM. The TQM Magazine, 14(3), 142-149. http://dx.doi.org/10.1108/09544780210425883

Li, T., \& Calantone, R. (1998). The Impact of Market Knowledge Competence in New Product Advantage: Conceptualization and Empirical Examination. Journal of Marketing, 62, 13-29. http://dx.doi.org/10.2307/1252284

Lumpkin, G. T., \& Dess, G. G. (1996). Clarifying the entrepreneurial orientation (EO) construct and linking it to performance. Academ of Management Review, 21(1), 135-172.

Lumpkin, G. T., \& Dess, G. G. (2001). Linking two dimensions of entrepreneurial orientation (EO) to business performance: The moderating role of environment and industry life cycle. Journal of Business Venturing, 16, 429-451. http://dx.doi.org/10.1016/S0883-9026(00)00048-3

Lumpkin, G.T., \& Dess, G.G. (1996). Clarifying the entrepreneurial orientation construct and linking it to performance. Academy of Management Review, 21(1), 135-172.

Lyons, K., Acsente, D., \& Waesberghe, M. (2008). Integrating knowledge management and quality management to sustain knowledge enabled excellence in performance. The journal of information and knowledge management systems, 38(2), 241-253.

Mabert, V. A., Soni, A., \& Venkataramanan, M. A. (2003). Enterprise Resource Planning: Managing the implementation process. European Journal of Operation Research, 146(2), 302-314. http://dx.doi.org/10.1016/S0377-2217(02)00551-9

Makadok, R. (2001). Toward a synthesis of the resource-based and dynamic-capability views of rent creation. Strategic Management Journal, 22(5), 387-401. http://dx.doi.org/10.1002/smj.158

McAdam, R. (2000). Quality models in an SME context. International Journal of Quality and Reliability Management, 17, 305-323. http://dx.doi.org/10.1108/02656710010306166

Mele, C., \& Colurcio, M. (2006). The evolving path of TQM: towards business excellence and stakeholder value. International Journal of Quality \& Reliability Managemen, 23(5), 464-489. http://dx.doi.org/10.1108/02656710610664569

Miller, D. (1983). The correlates of entrepreneurship in three types of firms. Management Sciense, 29, 770-791. http://dx.doi.org/10.1287/mnsc.29.7.770

Miller, D., \& Friesen, P. (1978). Archetype of strategy formulation. Management Journal, 31, 921-933.

Moghadami, S. (2005). Mysteries of organizational excellence. Tadbir Monthly Magazine, No.144.

Molina-Azorin, J. F., Tari, J. J., Claver-Cortes, E., \& Lopez-Gamero, M. D. (2009). Quality management, environmental management and firm performance: A review of empirical studies and issues of integration. International Journal of Management Review, 11(2), 197-222. http://dx.doi.org/10.1111/j.1468-2370.2008.00238.x

Moller, C. (2005). ERP II: a conceptual framework for next-generation enterprise systems?. Journal of Enterprise Information Management, 18(4), 483-497. http://dx.doi.org/10.1108/17410390510609626

Morris, M. H., Kuratko, D. F., \& Covin, J.G. (2008). Corporate entrepreneurship and innovation (2nd ed.). Thomson Higher Education, Mason.

Moullin, M. (2007). Performance measurement definitions: Linking performance measurement and organisational excellence. International Journal of Health Care Quality Assurance, 20(3), 81-3. http://dx.doi.org/10.1108/09526860710743327

NEELY, A., \& ADAMS, C. (2000). Perspectives on Performance: the performance prism. Handbook of Performance Measurement. London: Bouine.

Neely, A., \& Adams, C. (2001). The Performance Prism Perspective. Journal of Cost Management, January/February.

Neely, A., Gregory, M., \& Platts, K. (2005). Performance measurement system design: a literature review and research agenda. International Journal of Operations \& Production Management, 25(12), 1228-63. http://dx.doi.org/10.1108/01443570510633639

Nonaka, I., \& Takeuchi, H. (1995). The Knowledge-Creating Company: How Japanese Companies Create the Dynamics of Innovation. New York, NY.: Oxford University Press.

Oakland, J. S. (1995). Total Quality Management. Oxford: Butterworth-Heinemann. 
Oakland, J. S., \& Tanner, S. J. (2008). The relationship between Business Excellence and Performance - An empirical study using Kanji's Leadership Excellence Model. Total Quality Management, 19(7\&8), 733-749. http://dx.doi.org/10.1080/14783360802159402

Ooncharoen, N., \& Ussahawanitchakit, P. (2008). Building Organizational Excellence and Business Performance of Hotel Business in Thailand : Effects of Service Culture and Organizational Characteristics. International Journal of Business Research, 8(3), 13-26.

Osman, M. H., Rashid, M. A., Ahmed, F. S., \& Hussain, G. (2011). Entrepreneurial Orientation: An Overview of Theory and Insinuations for Women-owned SMBs to Model Business Performance in Developing Countries. Interdisciplinary Journal of Contemporary Research in Business, 3(3), 329-340.

Peters, J., \& Waterman, H. (1982). In Search of Excellence. Harper and Row: New York

Peters, T., \& Waterman, R. (1982). In Search of Excellence: Lessons from America's Best-Run Companies. New York: Harper \& Row.

Peters, T.J., \& Waterman, R.H. (1982). In Search of Excellence. Warner Books, New York, NY.

Pfau, L.D. (1989). Total quality management gives companies a way to enhance position in global marketplace. Industrial Engineering, 4, 17-18.

Pinar, M., \& Girard, T. (2008). Investigating the Impact of Organizational Excellence and Leadership on Business Performance: An Exploratory Study of Turkish Firms. SAM Advanced Management Journal, 73(1), 29-45.

Polanyi, M. (1962). Personal Knowledge- Towards a Post-Critical Philosophy. London, Routledge and Kegan Paul.

Pongatichat, P., \& Johnston, R. (2008). Exploring strategy-misaligned performance measurement. International Journal of Productivity and Performance Management, 57(3), 207-22. http://dx.doi.org/10.1108/17410400810857220

Porter, M. (1980). Competitive Strategy. Free Press, New York, NY.

Prahalad, C., \& Hamel, G. (1990). The Core Competence of the Organization. Harvard Business Review, (May-June), 79-90.

Prybutok, V. R., \& Ramasesh, R. (2005). An action research based instrument for monitoring continuous quality improvement. European Journal of Operational Research, 166(2), 293-309. http://dx.doi.org/10.1016/j.ejor.2004.02.013

Rahman, S. (2001a). A comparative study of TQM practice and organizational performance of SMEs with and without ISO 9000 certification. International Journal of Quality \& Reliability, 18(1), 35-49. http://dx.doi.org/10.1108/02656710110364486

Rahman, S. (2001b). Total quality management practices and business outcome: evidence from small and medium enterprises in Western Australia. Total Quality Management \& Business Excellence, 12(2), 201-210.

Ramlall, S. J. (2002). Measuring Human Resource Management's Effectiveness in Improving Performance.

Rauch, A., Wiklund, J., Lumpkin, G., \& Frese, M. (2009). Entrepreneurial orientation and business performance: an assessment of past research and suggestions for the future. Entrepreneurship Theory Pract, 33(3), 761-787.

Reed, R., Lemak, D. J., \& Mero, N., P. (2000). Total Quality Management and sustainable competitive advantage. Journal of Quality Management, 5, 5-26. http://dx.doi.org/10.1016/S1084-8568(00)00010-9

Riahi, B. (2005). Evaluation of the organization performance based on EFQM organizational excellence model. Journal of Administrative change, (47).

Russo, M., \& Fouts, P. (1997). A resource-based perspective on corporate environmental performance and profitability. Academy of Management Journal, 40(3), 534-559. http://dx.doi.org/10.2307/257052

Salaheldin, S. I. (2009). Critical success factors for TQM implementation and their impact on performance of SMEs. International Journal of Productivity and Performance Management, 58(3), 215-237. http://dx.doi.org/10.1108/17410400910938832

Salekzamani, M. (2006). Frameworks of business excellence: tool number one: productivity. Standard Monthly Magazine, (171).

Sandoe, K., Corbitt, G., \& Boykin, R. (2001). Enterprise integration. New York, NY: Wiley. 
Scalle, C.X., \& Cotteleer, M.J. (1994). Enterprise Resources Planning (ERP). Boston, MA: Harvard Business School Publishing

Shad, S., Chen, E., \& Azeem, F. M. (2011). Performance Enhancement Factors of ERP Projects in a Telecom Public Sector Organization of Pakistan: An Exploratory Study. Interdisciplinary Journal of Contemporary Research in Business, 2(11), 95-109.

Sharma, M., \& Kodali, R. (2008). TQM implementation elements for manufacturing excellence. The TQM Magazine, 20(6), 599-621. http://dx.doi.org/10.1108/17542730810909365

Shiba, S., Graham, A., \& Walden, D. (1993). A New American TQM. Productivity Press, Portland, OR.

Sink, D., \& Tuttle, T. (1989). Planning and measurement in your organization of the future. Norcross, GA: Industrial Engineering and Management Press.

Slevin, D.P., \& Covin, J.G.(1990). Juggling Entrepreneurial Style and Organizational Structure-How to Get Your Act Together. Sloan Management Review, Winter, 43-53.

Smart, D. T., \& Conant, J. S. (1994). Entrepreneurial orientation (EO), distinctive marketing competencies and organizational performance. Journal of Applied Business Research, 10, 28-38.

Subramaniam, M., \&Youndi, H. (2005). The Influence of Intellectual Capital in the Types of Innovative Capabilities. Academy of Management Journal, 48, 450-63. http://dx.doi.org/10.5465/AMJ.2005.17407911

Sveiby, K. (2001). A Knowledge-based Theory of the Firm to Guide in Strategy Formulation. Journal of Intellectual Capital, 2(4), 344-358. http://dx.doi.org/10.1108/14691930110409651

Tarn, M., Yen, D., \& Beaumont, M. (2002). Exploring the rationales for ERP \& SCM integration. Industrial Management \& Data Systems, 102(1), 26-34. http://dx.doi.org/10.1108/02635570210414631

Teece, D. J., Pisano, G., \& Shuen, A. (1997). Dynamic capabilities and strategic Management. Strategic Management Journal, $18, \quad 509-533$. http://dx.doi.org/10.1002/(SICI)1097-0266(199708)18:7<509::AID-SMJ882>3.0.CO;2-Z

Timmons, J. (1999). New Venture Creation: Entrepreneurship for the Twenty-first Century (5th ed.). McGraw-Hill International Editions, Boston, MA.

Umble, E. J., Haft, R. R., \& Umble, M. M. (2003). Enterprise resource planning: Implementing procedures and critical success factors. European Journal of Operational Research, 146, 241-257. http://dx.doi.org/10.1016/S0377-2217(02)00547-7

Velcu, O. (2007). Exploring the effects of ERP systems on organizational performance. Industrial Management \& Data Systems, 107(9), 1316-34. http://dx.doi.org/10.1108/02635570710833983

Wernerfelt, B. (1984). A resource-based view of the firm. Strategic Management Journal, 5, 171-180. http://dx.doi.org/10.1002/smj.4250050207

Wieder, B. et al. (2006). The impact of ERP systems on firm and business process performance. Journal of Enterprise Information Management, 19(1), 13-29. http://dx.doi.org/10.1108/17410390610636850

Wiklund, J. (1999). The sustainability of entrepreneurial orientation (EO)-performance relationship. Entrepreneurship Theory and Practice, 24(1), 37-48.

Wiklund, J., \& Shepherd, D. (2003). Knowledge-based resources, entrepreneurial orientation, and the performance of small and medium sized business. Strateg Manag J, 24(13), 1307-1314. http://dx.doi.org/10.1002/smj.360

Wiklund, J., \& Shepherd, D. (2003). Knowledge-Based Resources, Entrepreneurial Orientation, and the Performance of Small and Medium-Sized Business. Strategic Management Journal, 24, 1307-1314, http://dx.doi.org/10.1002/smj.360

Wiklund, J., \& Shepherd, D. (2005). Entrepreneurial orientation (EO) and small business performance: a configurational approach. Journal of Business Venturing, 20, 71-91. http://dx.doi.org/10.1016/j.jbusvent.2004.01.001

Williams, C.C., Round, J., Rodgers, P. (2010). Explaining the off-the-book enterprise culture of Ukraine: reluctant or willing entrepreneurship?. Int J Entrepreneurship Small Bus, 10(2), 165-180. http://dx.doi.org/10.1504/IJESB.2010.033107

Yang, C., Ting, P., \& Wei, C. (2006). A Study of the Factors Impacting ERP System Performance-from the Users' Perspectives. The Journal of American Academy of Business, 8(2), 161-166. 
Yong, J., \& Wilkinson, A. (1999). The state of total quality management: A review. The International Journal of Human Resource Management, 10(1), 137-161. http://dx.doi.org/10.1080/095851999340684

Yusof, S. M., \& Aspinwall, E. (2000). Total quality management implementation frameworks: comparison and review. Total Quality Management, 11(3), 281-374. http://dx.doi.org/10.1080/0954412006801

Zack, M. (1999). Managing Codified Knowledge. Slaan Management Review, Summer, 45-58.

Zahra, S. A. (1999). The Changing Rules of Global Competitive in the 21st Century. Academy of Management Executive, 13(1), 36-42.

Zahra, S. A., \& Covin, J. (1995). Contextual influences on the corporate entrepreneurship-performance relationship: A longitudinal analysis. Journal of Business Venturing, 10, 43-58. http://dx.doi.org/10.1016/0883-9026(94)00004-E

Zahra, S. A., \& Garvis, D. M. (2000). Entrepreneurship and firm performance: The moderating effect of international environmental hostility. Journal of Business Venturing, 15(5), 469-492. http://dx.doi.org/10.1016/S0883-9026(99)00036-1

Zahra, S.A. (1986). A Canonical Analysis of Corporate Entrepreneurship Antecedents and Impact on Performance. Proceedings of the National Academy of Management, 46, 71-5.

Zahra, S.A. (1999). The changing rules of Global competitiveness in the 21st Century. Academy of Management Executives, 13, 36-42.

Zairi, M. (1994). Leadership in TQM implementation: Some case examples. The TQM Magazine, 6(6), 9-16. http://dx.doi.org/10.1108/09544789410073586

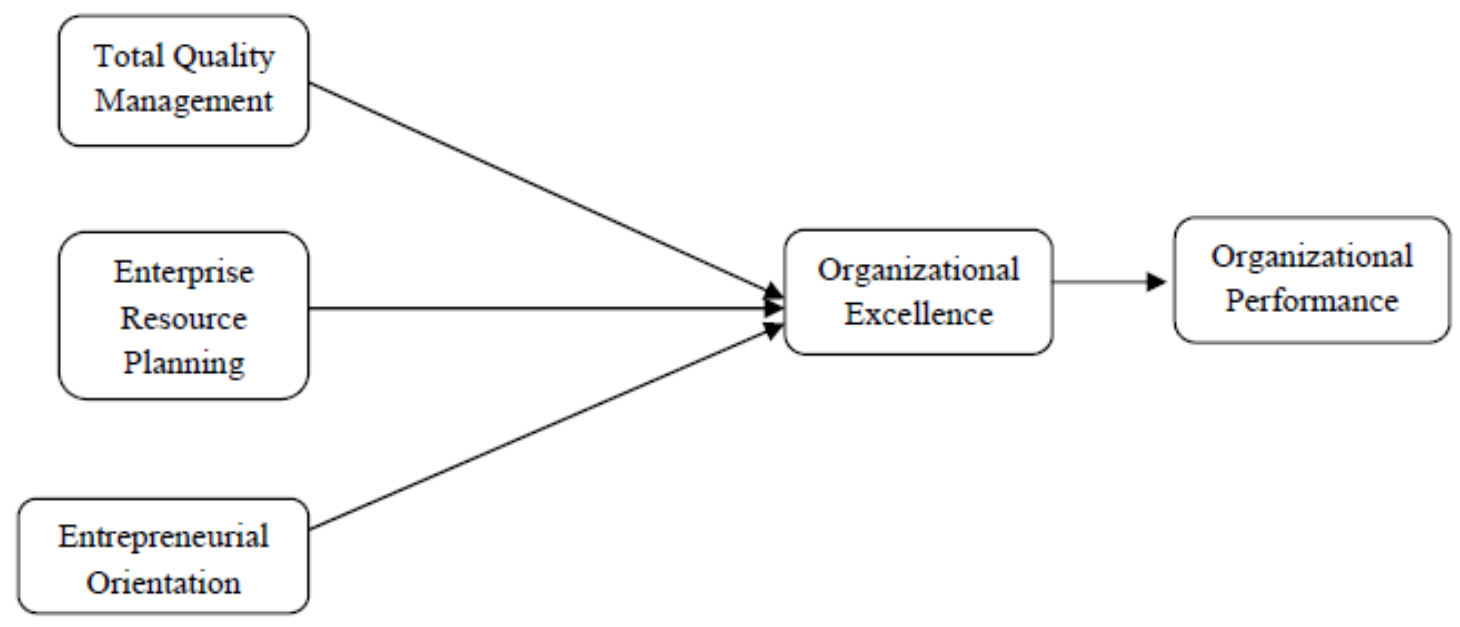

Figure 1. Theoretical research framework 